\title{
Geotechnical aspects of mud eruption disaster In East Java
}

\author{
Paulus P. Rahardjo ${ }^{\text {i) }}$
}

i) Professor, Department of Civil Engineering, Parahyangan Catholic University, Ciumbuleuit 94, Bandung 40142, Indonesia.

\begin{abstract}
Mud eruption occured in East Java, 3 days after the Jogyakarta Earthquake in May 26, 2006 where at the site, deep drilling was being conducted. The mechanism of the causes of the eruptions are still in debate, whether trigerred by the drilling or pressurised fluid reactivated by the quake. However the objectives of this paper is to discuss mainly on the geotechnical aspects of the mud eruption which spread in larger area until today.

In the early days of eruption, as much as 150,000 cubic meters discharge per day was reported, although presently only less than 5000 cubic meters of the discharge is estimated. Due to unknown characteristics of the mud, dykes were constructed to contain the mud and the areas being much larger to reach 450 hectares in 2006 and becoming larger in 2007. The location of the disaster is just in the middle of the town of Porong in the district of Sidoardjo, where the Surabaya International airport is located and has block the major arterial roads from north to south of east Java.

The soil condition of the site is deep soft clays which causes instability of the dykes. Some dyke failures occured which endangered the residential areas due to the flow of the mud. This paper desscribe the characterics of the soil conditions from a number of drillings and CPTu conducted by the author for design of the replacement of the arterial road, west of the site. The paper discuss the geotechnical problems of land subsidence in large areas and differential settlement that causes damages of the infrastructures, including the roads, gas pipes, railways, the bridges and the buildings. The mud has been discharged through the Porong river, and the sedimentation is being part of the problems.
\end{abstract}

Keywords: Mud eruption, soft soils, geotechnical failures, land subsidence

\section{INTRODUCTION}

The mud disaster in east Java is one of special event which is very rare. Mud eruption occured on May 29, 2006 is the biggest of its kind in the world. It was preceeded by the drilling for gas exploration conducted at this area. However some speculation of judgement occurred until this day, whether the eruption is triggered by the drilling or by the Jogjakarta earthquake of May 26, 2006. The disaster has caused 14 fatalities, displaced 30,000 people (13,000 families), closed 30 factories and hundreds of small business and more than 10,000 homes flooded by the mud in more than dozen of villages. This paper is mainly dealing with the geotechnical aspects of this occurance that become the concern of the government of Indonesia for risk reduction.

The location of this Mud Eruption is at Porong, the southern district of Sidoardjo regency, about $12 \mathrm{~km}$ south of the town of Sidoardjo, where the Surabaya International Airport is located. Figure 1 shows the location of mud eruption, and figure 2 shows the district of Sidoardjo, the most affected area.

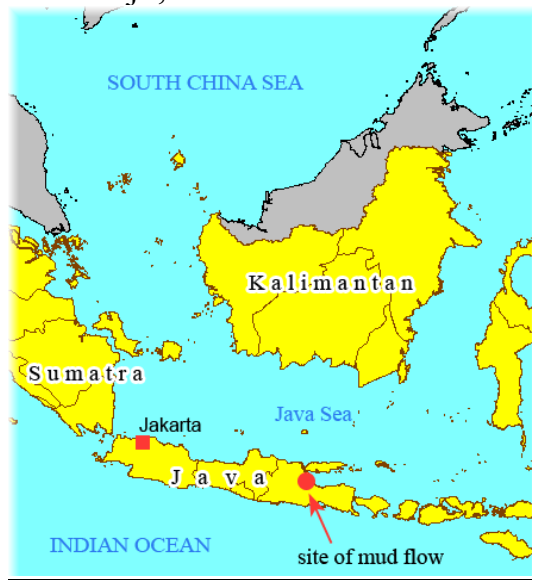

Fig. 1. Location of the Mud Eruption in East Java, Indonesia

The site is a residential area and is surounded by the main industrial area in East Java. The Surabaya Gempol toll road, highway Surabaya - Malang Pasuruan - Banyuwangi which form important economic route in East Java are directly influenced by 
this Mud. Since the location is close to Surabaya, the second largerst city in Indonesia, and surrounded by dense population, practically the disaster has significant disturbance on the economic stability and social life of the area, specially east java.

Despite of many efforts conducted to reduce the eruption, the scale of the disaster is beyond the capability of human beings. As a result, the last effort is merely defence to save the life of the people and to limit the widening effect to the surrounding by pumping the mud into the Porong river, which in the long run creating new problems.

The disaster has become the world most destructive mud volcano (Wayman, 2011). But at present after almost 9 years the discharge has dropped much less, this gives hope on whether the eruption is almost over, but some geologists predicted that the mud will end 30 years from the start of the disaster.

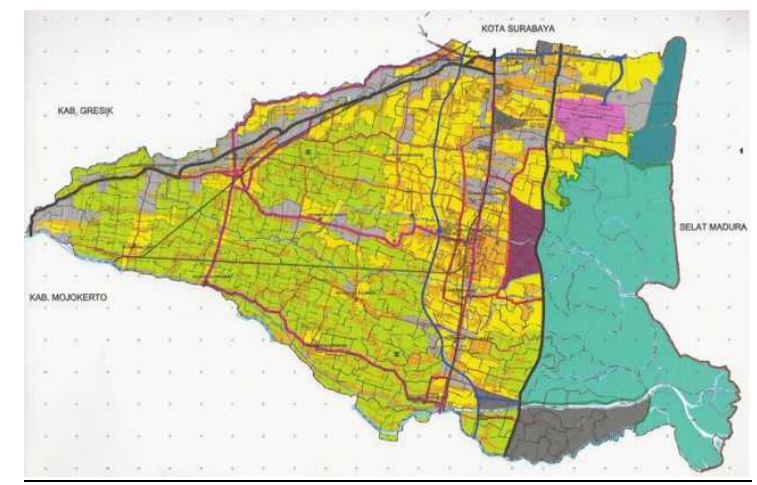

Fig. 2. Location of the Mud Eruption amids the economic activities of the District of Sidoardjo which is densely populated

The mud ejected through this volcano is hot, and at the nearby collected samples, the temperatures measured is in the range of 80-90 Celcius degrees. Figure 3 shows the center of the mud eruption.

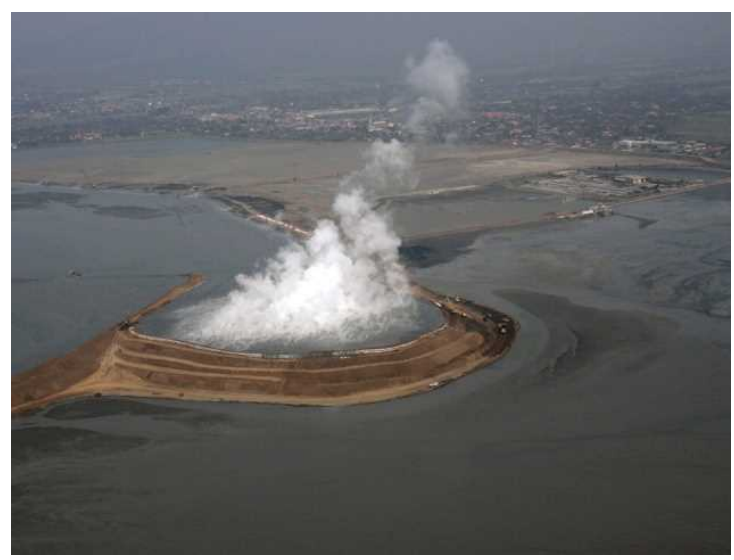

Fig. 3. The vent of the Mud Eruption in East Java, Indonesia, surrounded by protection dykes (Boston.com, 2008)

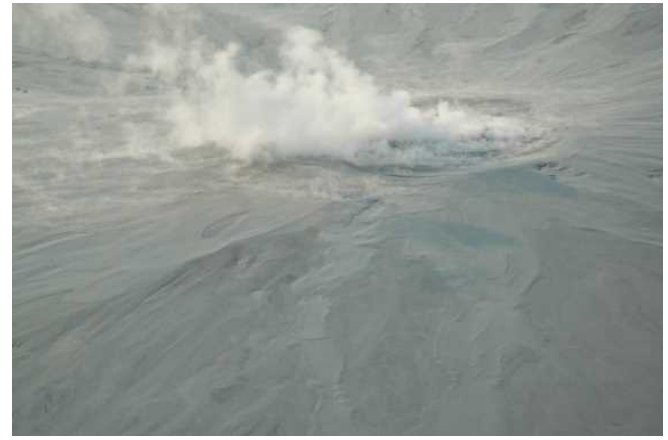

Fig. 4. The center of the Mud Eruption (BPLS,2007)

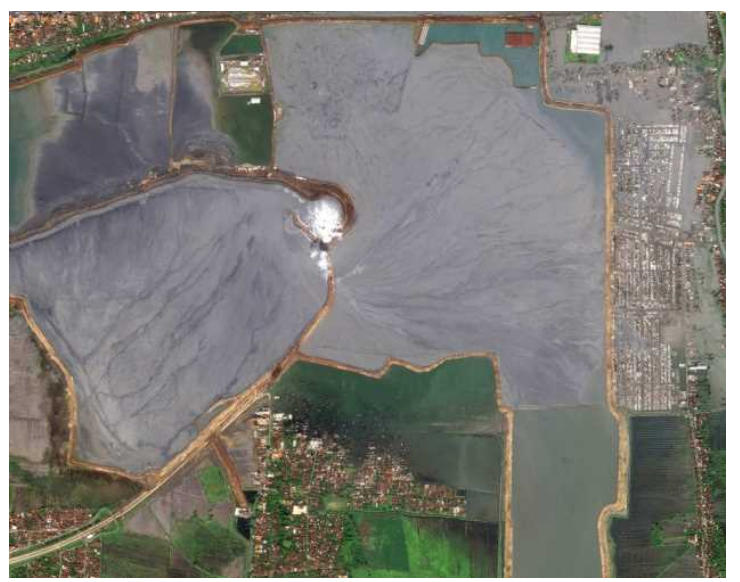

Fig. 5. The spreading of the Mud Eruption in the district of Sidoardjo, East Java and the cells with protection dykes (CRISP)

\section{THE CAUSE OF MUD ERUPTION}

The conditions prior to mud eruption was the drilling for gas exploration by a company in Indonesia, known as Banjar Panji 1 which had reached about $3000 \mathrm{~m}$ depth. Richard Davis, a geologist at Durham University in England believes that due to the drilling the gas released, created failure of the surrounding rock and materials being washed out to the surface. Figure 6 shows the mechanism as illustrated in the National Geographics (2006). Michael Manga, a geologist at the University of California Berkeley explained the overlying sediments compress the lower layers and pressure builds as the upper layers get thicker and heavier,and the squeezed water has no where to go. If a path to surface opens, the highly pressurized water will shoot up (in article rewritten by Wayman, 2011)

However some other opinions such as Adriano Mazzini of the University of Oslo have raised the occurance as being reactivation of the fault nearby due to the Yogyakarta shallow earthquake of magnitude $\mathrm{M}=6.3$ which also believed to have reactivated the Opak Fault along south of Yogjakarta to Central Java near Prambanan Temple. Stephen Miller, a geophysicist at the University of Bonn who led research on "Seismic Energy from the quake, reflected and focused by the surrounding rocks became 
sufficiently concentrated to liquefy the mud source. According to the study, the mud fluid then injected itself into the adjacent Watukosek Fault and caused it to slip, thus linking it to hydrothermal volcanic system deeper down, so that the previously trapped system completely rearranged itself and fatally, got connected to free the surface. Then the mud came

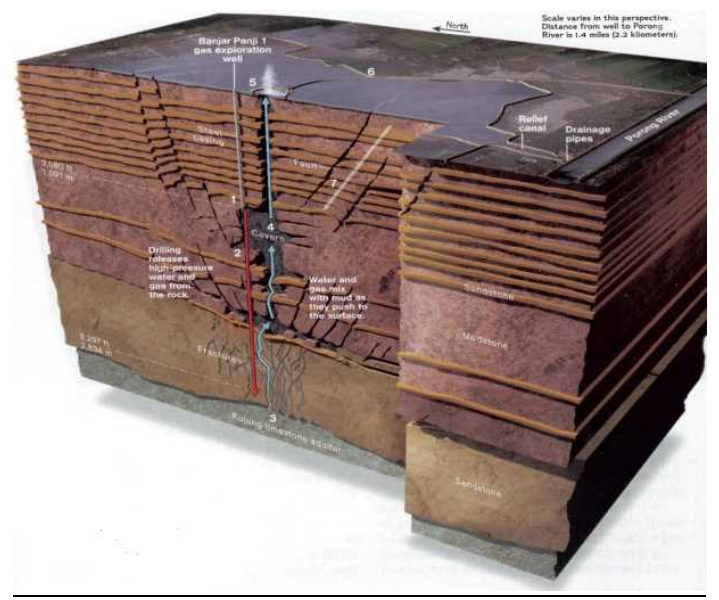

Fig. 6. The mechanism of the start of mud eruption (National Geographic, 2006)

Since 8 April 2010, there have been a dramatic changed. The old Lusi crater (since May 29, 2006) has died. The current speed of burst at minimum condition approxilamtely $<5000 \mathrm{~m} 3$ a day compared to the peak rate at the begining $180,0000 \mathrm{~m} 3 /$ day decreasing to around $100,000 \mathrm{~m} 3$ in 2008/2009. Currently the model of Lusi Volcano is very much similar to Bledug Kuwu (in Central Java) indicated by a kick of mud without flow or waves (Hady Prasetyo 2010).

\section{CHARACTERISTICS OF THE MUD AND MUD REMOVAL}

The mud is very soft, consisting about $70 \%$ of water, and the material being clayey silts and very fine sands with gravel. This mud is difficult to handle because of the high liquidity and not easy to be removed except by mud pump. Figure 7 shows mud characteristic in wet condition and figure 8 shows the mud characteristics in drying condition

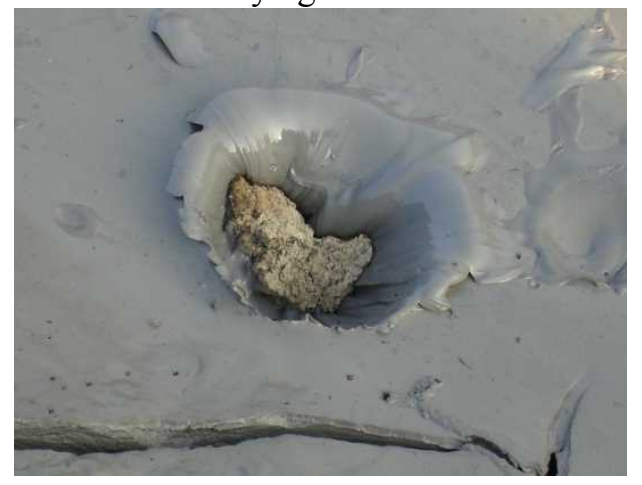

Fig. 7. The visual condition of mud characteristics (BPLS,2007)

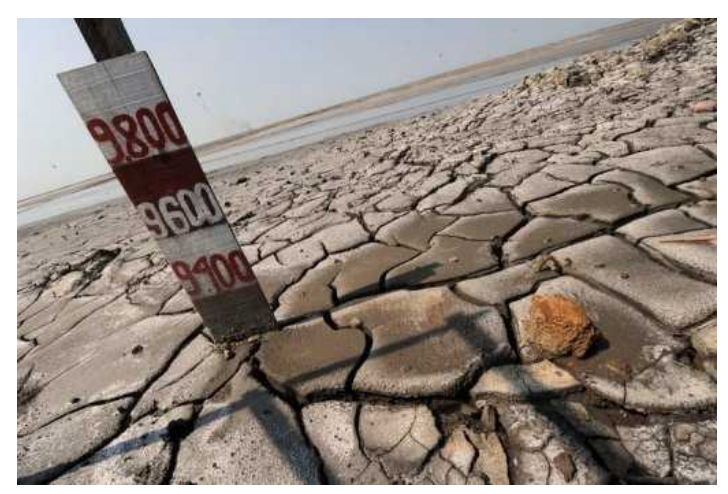

Fig. 8. Condition of the mud upon drying (hufingtonpost.com, July 22, 2013)

After sufficiently mixed with water the mud is pumped to the river which in turn may cause other problem of sedimerntatiom like seen on figure 9 .

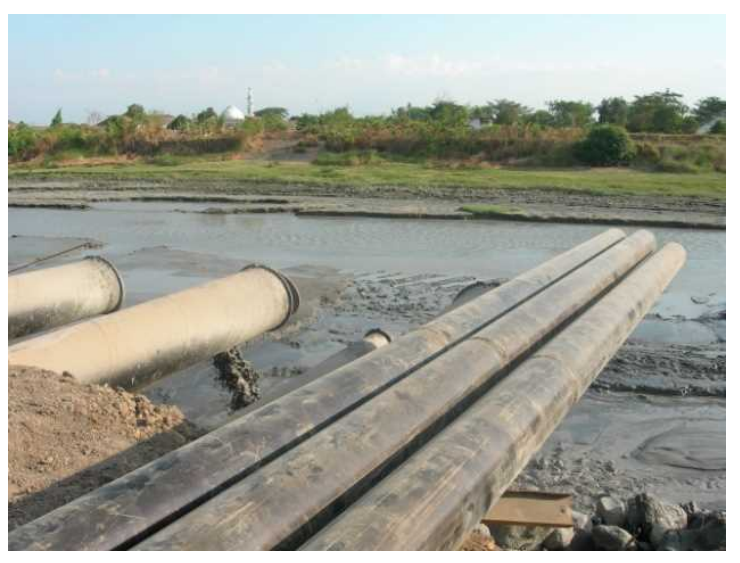

Fig. 9. Removal of the mud through Porong River (BPLS,2007)

\section{THE DAMAGES DUE TO MUD ERUPTION}

The main damages to infrastructure mainly in thousands of houses being flooded including schools, mosques, 30 factories etc, the toll road of Surabaya Gempol, Arterial Road Surabaya - Malang, Railways, Gas pipes, Drainage Canals and many others causing economic losses in the order of billions of US dollars. The economic and social activities are significantly direct or indirectly affected.

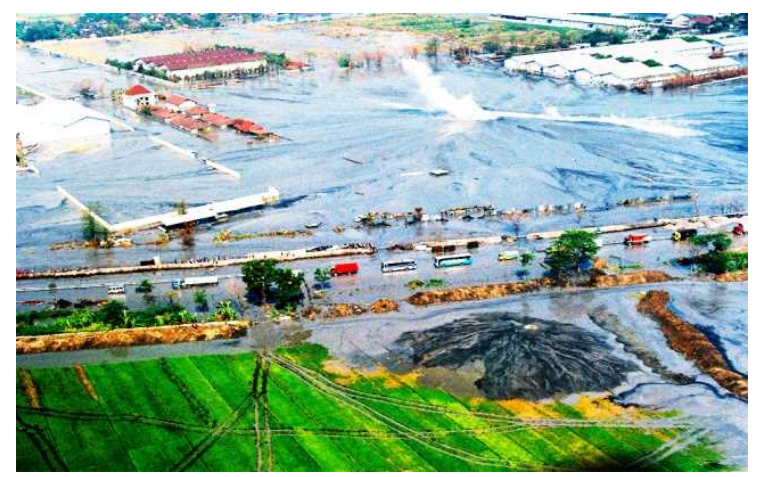

Fig 10. Damages to the infrastructures (BPLS 2007) 

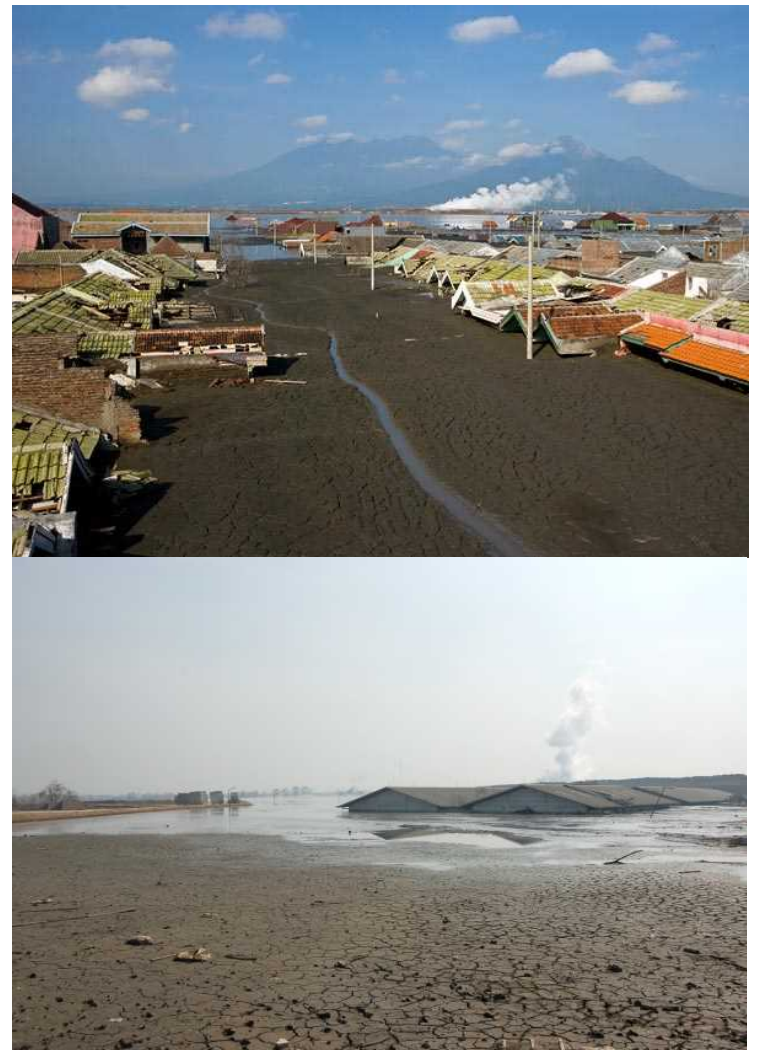

Fig 11. Damages to the muddy flooded houses (BPLS 2007)

Figure 10 shows the range of spreading of the mud in 2007 where the highway of Surabaya-Gempol was still in use. The author has reviewed the condition of the dyke and water started seeping at the toe of the slope, which means that the dyke was not safe. In the same year, this highway was flooded by the mud and no longer used.

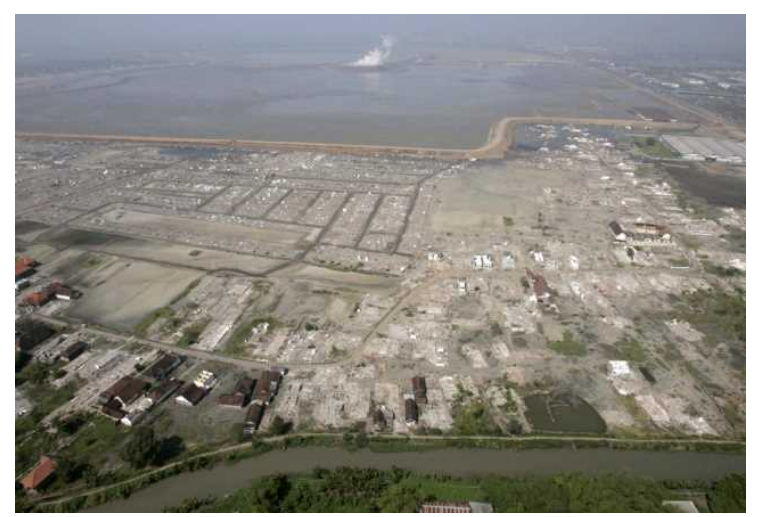

Fig 12. View of the mud from Porong River (BPLS 2007)

\section{GEOTECHNICAL ASPECT OF MUD DISASTER AND EFFORT TO REDUCE RISK}

\subsection{Soils condition at site}

Based on laboratory tests in this area, the soils are highly plastic materials, the natural water content ranges from $40-100 \%$. Generally the upper part is slightly stronger showing slight overconsolidation. However the void ratio could be as high as $1.5-3.0$. Laboratory consolidation tests also show that the soft soils is still consolidating. Compressibility of the soils as measured from its compression index is very high with a range of $0.5-1.5$. This explain why settlement is large (Soleman, 2012)

Drilling soils or CPT on sites are impossible due to the existence of shallow gas and psychological condition of the people who have trauma from the drilling. However the soil investigation used for describing the condition of the soils on site may be done by old soil test as well as from the new soil investigation for the construction of the alternative arterial roads. The author has done drilling as well as $\mathrm{CPTu}$ for the new arterial road. Figure 13 shows typical condition of the soil on site from CPTu tests. The soils are not only soft but there is indication that the soft soils are still consolidating judging from the value of pore pressure ratio $\mathrm{Bq}$.

Based on insitu testings (CPTu and SPT), the soil upper layers are very soft with thickness of 15-25 $\mathrm{m}$ dominated by clays to silts and silty sands. The silty sands are mixed with clay

This soil condition has very low bearing capacity and may cause very large settlement upon loading. The possibility of squeezing of lower soil layers are among the problems that need to be considered.

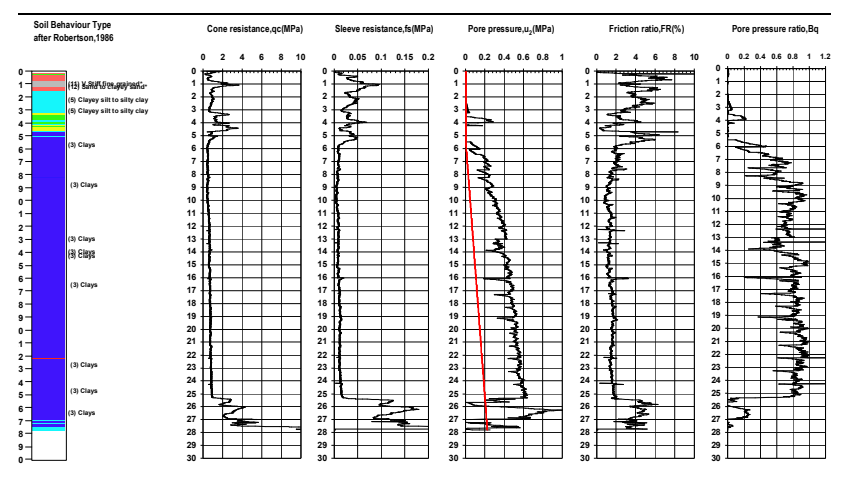

Fig. 13. Soil profiles at the location of Mud Eruption (PT GEC)

\subsection{Stability of dykes to contain the mud}

Due to the unknown condition of the mud, hence the only possibility of saving human beings is by containing the mud in cells where the cells boundary were the dykes. Figure 14 shows the dykes boundary in 2007. But then it was kept as it is due to the possibility that the mud is allowed to be removed through Porong river. 
The dykes were constructed using gravelly sands and most of them were not well designed. The reason simply because there is not sufficient time for investigation nor for compaction. Figure 16 shows emergency construction of dykes due to the mud spread over the arterial road. The compaction was conducted mainly by the dozers and quality control was not possible. Other problem related to the dykes safety is due to the fact that the foundation soils are mostly soft with thickness from $5 \mathrm{~m}$ to 30 meter depth.

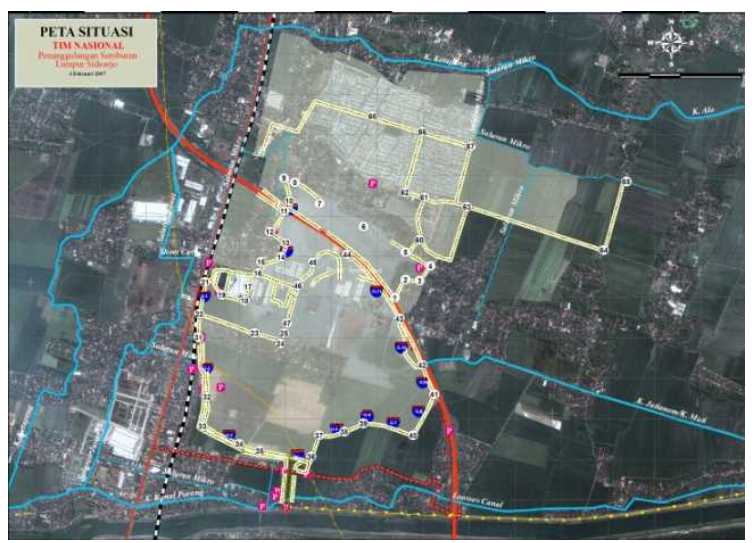

Fig. 14 Cells to contain the mud (Tim Nasional)

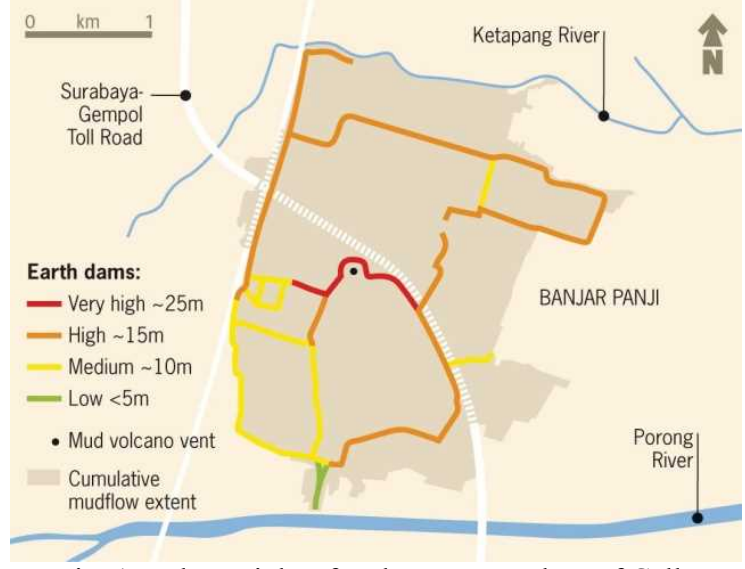

Fig. 15. The Height of Dykes as Boundary of Cells

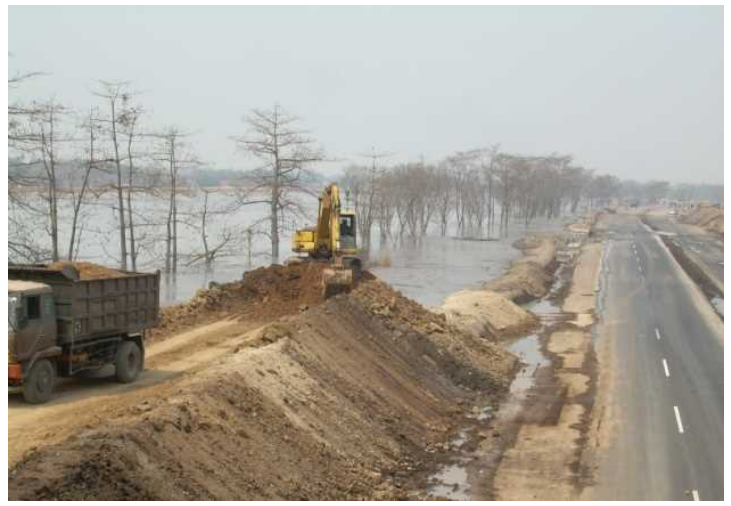

Fig. 16 Construction of Permanent Dykes (BPLS 2007)

Due to the soft foundation soils, the dykes frequenly failed and move laterally which could endangered the prople surrounding the area. In August
22, 2010, particular accident accompanied by sudden floods landslides (such as cold lahar) in the south east , a phenomena that has occured debris flow and sediment gravity flow (Hardy Prasetyo, 2010). 'In a matter of minutes, three dredgers that were operationg there have been driven as far as $200 \mathrm{~m}$ from its original position. Figure 8 shows typical failure condition of the dykes. Immediate repair is generally done with enlarging the size of the dykes or by construction of counter weight.

Figure 16 shows maintenance of dykes in the center that now has reached $25 \mathrm{~m}$ high due to the continuous settlement. As the dykes became higher, stability has become particular concern (figure 18). To reduce the amount of fill, large sand bags have been used to replace the fill embankment (figure 19).

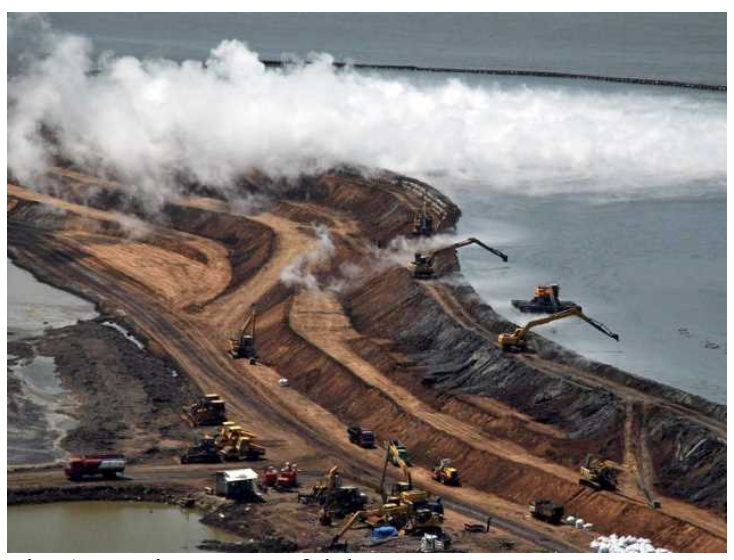

Fig. 17. Maintenance of dykes

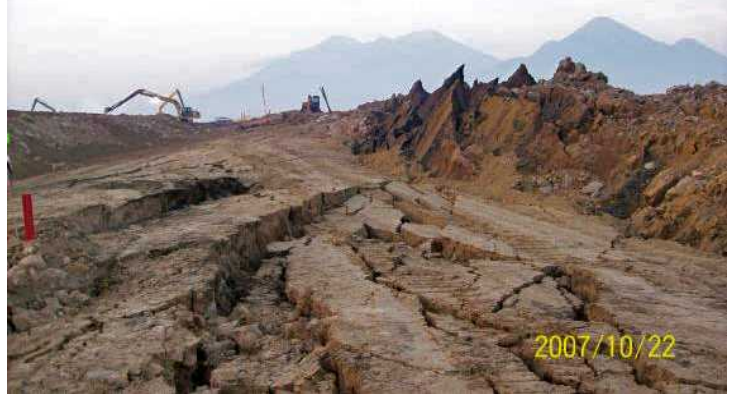

Fig. 18. Dykes slide and lateral movement (BPLS 2007)

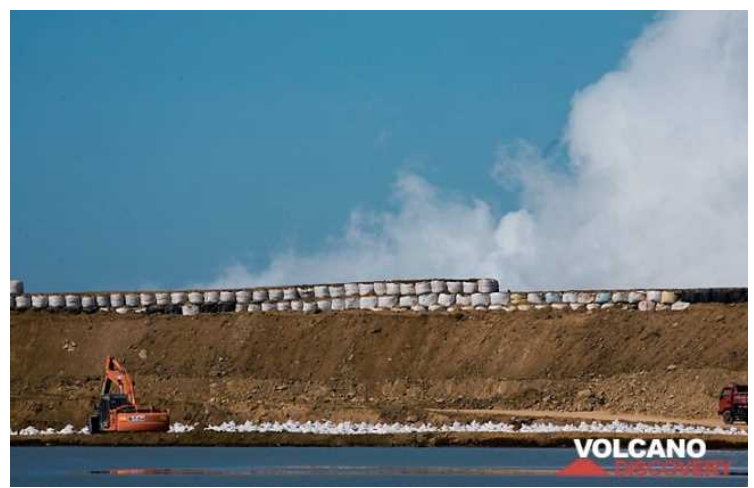

Fig. 19. Additional fill around the main source dykes due to settlement problem (Volcano Discovery) 


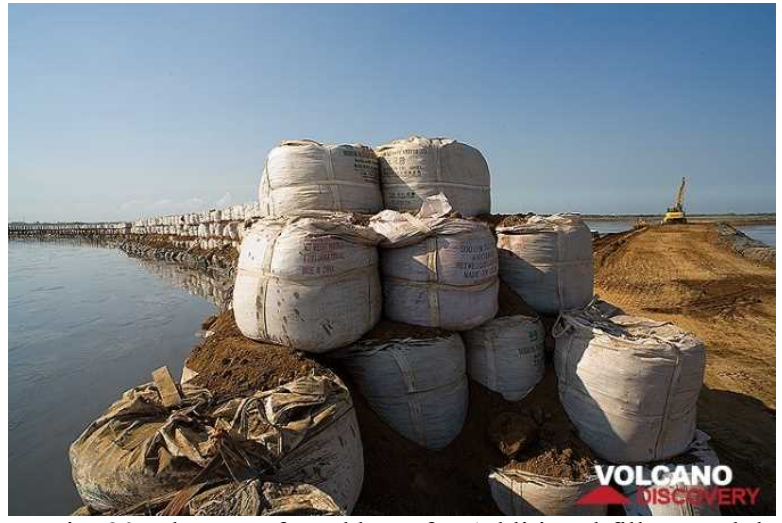

Fig. 20. The use of sand bags for Additional fill around the main source dykes due to settlement problem (Volcano Discovery)

\subsection{Land subsidence and Settlement Problems}

At the center of the vent, the land sink because so much water and mud from beneath the ground have erupted. To maintain the height of the dykes, large sandbags are being used as shown on figure 19 and figure 20. But also the surrounding land indicates settlement and based on measurement, the affected area is at radius of $1.5 \mathrm{~km}$. Pressure in the pond has caused settlement of the surrounding area including serious settlement along the dykes. Feasibility Study of Settlement (TKKP) from ITS since November 2009 recorded settlement in the order of $10 \mathrm{~cm}$ per month. The average drop of settlement within a period of six month may reach $150 \mathrm{~cm}$. On the other hand land in the western and Jatirejo Siring Village has roused to about 1.0-3.0 $\mathrm{m}$. This could be due to deep sliding

\section{CONCLUSIONS}

Based on the study, some conclusions are made :

The soil conditions underneath the mud eruption and the area of mud containement are generally very soft. This condition rise serious problem of stability and subsidence. In most cases, the soils are still consolidating and sensitive to disturbance. Additional laodind will be very dangerous.

There is a chance for improvement due to the significant decrease in mud discharge. Reclamation may be proposed.

The mud discharge to Porong river might cause long term problem due to the sedimentation along the river and in the estuary area.

\section{ACKNOWLEDGEMENTS}

The author appreciate the help of Lembaga Penelitian dan Pengabdian Masyarakat (LPPM) of Parahyangan Catholic University for providing fund to do work on this research and to BPLS and engineers of PT GEC for providing information and data.

\section{REFERENCES}

1) BPLS (Badan Penangulangan Lumpur Sidoardjo) (2007) : Personal Communication with Mr. Sofyan

2) Boston.com (2008) : Sidoardjo's Man-made Mud Volcano

3) GEC, PT., (2009) : Soil investigation Report Using CPTU for the alternative by pass road at Porong, Report

4) Guntoro, A (2011) : Understanding the Origin of Sidoardjo Mud Volcano in Relation to Longevity Estimation Based on Regional Study and Seismic Interpretation, Lectures at Geological Department Trisakti University, Jakarta

5) Kompas (22 June 2010) : Lapindo Mud Resulted in Building Fracture, Surabaya

6) Rahardjo, P.P. (2011) : Geotechnical Aspect of Sidoardjo Mud Eruption (in Indonesian), report, Center for Infrastructures and Urban Development, Parahyangan Catholic University

7) Soleman, A.R. (2012): Karakterisasi Tanah Lempung Lunak di Porong Sidoardjo berdasarkan Uji CPTu dan Uji Laboratorium, tesis Magister, Universitas Katolik Parahyangan, Bandung.

8) Wayman, E.(2011) : The World's Muddiest Disaster, Smithsonian.com, December 2, 2011 